\title{
PENERAPAN PEMBELAJARAN EXPERIENTIAL LEARNING UNTUK MENINGKATKAN KUALITAS PEMBELAJARAN IPA KELAS V SEKOLAH DASAR
}

\author{
Septi Aprilia \\ Prodi PGSD FIP IKIP PGRI MADIUN
}

\begin{abstract}
This research aims to improve the outcomes of student learning and teacher skills in learning science by implementing the experiential learning model. This research is an action class research which is done in two cycles. The subjects of this research are teacher and students in fifth grade on Bulukantil Elementary School of Surakarta academic year 2014/1015. Data collection techniques used the methods of test and observation. Based on the results of the research shown increasing in the average of studied results from cycle I to cycle II from 61, 07 with percentage of 60,7 \% to 75,09 with percentage rose to $85 \%$. The research also shown increase in the skills of teachers, on average cycle I teacher skills was 3, 11 with percentage of $48.3 \%$ (good in scale) in cycle II rose to 3,5 with percentage $88.8 \%$ (very good in scale). As a result the experiential learning model can improve the quality of learning that can be suggested to apply in learning especially in natural science.

Keyword: experiential learning model, Study result, teacher skills
\end{abstract}

\begin{abstract}
Abstrak
Penelitian ini bertujuan untuk meningkatkan hasil belajar siswadan keterampilan guru dalam pembelajaran IPA melalui penerapan model experiential learning. Penelitian ini merupakan penelitian tindakan kelas yang dilakukan dalam dua siklus. Subyek penelitian ini adalah guru dan siswa kelas V SDN Bulukantil Surakarta, tahun pelajaran 2014 / 2015 dengan jumlah siswa sebnyak penelitian 30 siswa. Teknik pengumpulan data menggunakan tes dan observasi. Berdasarkan hasil penelitian menunjukkan adanya peningkatan rata-rata hasil belajar siswa dari siklus I ke siklus II dari 61,07 dengan ketuntasan belajar sebesar 60,7\% menjadi 75,09 dengan ketuntasan belajar naik menjadi 85\%. Dan menunjukkan peningkatan keterampilan guru, pada siklus I rata-rata keterampilan guru yang diperoleh 3,11 dengan persentase $77.7 \%$ (baik), siklus II meningkat menjadi 3,5 dengan persentase $88.8 \%$ (sangat baik). Dengan demikian model experiential learningdapat meningkatkan kualitas pembelajaran sehingga disarankan dapat diterapkan terutama pada pembelajaran IPA.
\end{abstract}

Kata kunci: model experiential learning, hasil belajar, keterampilan guru. 


\section{A. Pendahuluan}

Salah satu tujuan belajar adalah bukan semata- mata berorientasi pada penguasaan materi dengan menghafal faktafakta yang tersaji dalam bentuk informasi atau materi pelajaran. Lebih jauh dari pada itu, orientasi sesungguhnya dari proses belajar adalah memberikan pengalaman untuk jangka panjang. Dengan konsep ini diharapkan hasil pembelajaran menjadi lebih bermakna bagi siswa. Proses pembelajaran berlangsung secara alamiah dalam bentuk kegiatan murid bekerja dan mengalami, bukan transfer pengetahuan dari guru ke siswa.

IPA diharapkan dapat menjadi wahana bagi peserta didik untuk mempelajari dirisendiri dan alam sekitar, serta prospek pengembangan lebih lanjut dalam menerapkannya didalam kehidupan seharihari. Proses pembelajaran IPA yang dilakukan harus dapat mengeksplorasi wawasan pengetahuan siswa, menumbuhkan kemampuan berpikir, bekerja dan bersikap ilmiah serta mengkomunikasikannya sebagai aspek penting kecakapan hidup. Oleh karena itu pembelajaran IPA di SD/MI menekankan pada pemberian pengalaman belajar secara langsungmelalui penggunaan dan pengembangan keterampilan proses dan sikap ilmiah. (Depdiknas, 2007 : 484). Salah satu alternatif model pembelajaran yang digunakan untuk menjawab permasalahan diatas adalah dengan menggunakan model experiential learning.

Menurut Mahfudin (dalam Abdul Majid: 2014) model pembelajaran experiential learning merupakan model pembelajaran yang diharapkan dapat menciptakan proses belajar yang lebih bermakna, dimana siswa mengalami apa yang mereka pelajari. Melalui model ini, murid tidak hanya belajar tentang konsep materi belaka, hal ini dikarenakan murid dilibatkan secara langsung dalam proses pembelajaran untuk dijadikan suatu pengalaman. Hasil dari proses pembelajaran experiential learning tidak hanya menekankan pada aspek kognitif saja, tetapi aspek afektif dan psikomotorik.

Berkaitan dengan hal tersebut maka perlu dilakukan penelitian tindakan kelas dengan judul "Penerapan Model Experiential Learning untuk Meningkatkan Kualitas Pembelajaran IPA Pada Siswa Kelas V SDN Bulukantil Surakarta.

\section{B. Kajian Pustaka}

\section{Model experiential learning}

Model experiential learning menekankan pada sebuah model pembelajaran yang holistik dalam proses belajar. Model experiential learning merupakan suatu model proses belajar mengajar yang mengaktifkan pebelajar (siswa) untuk membangun pengetahuan dan keterampilan melalui pengalamannya secara langsung. Model experiential learning memberikan kesempatan kepada siswa untuk memutuskan pengalaman apa 
yang menjadi fokus mereka, keterampilan-keterampilan yang ingin mereka kembangkan dan bagaimana cara mereka membuat konsep dari pengalaman yang mereka alami tersebut.

Menurut Abdul Majid (2014), Model experiential learningterdiri dari empat tahapan, yaitu :

a. Tahapan pengalaman nyata;

b. Tahapan Observasi refleksi;

c. Tahapan konseptualisasi;

d. Tahapan implementasi.

Dalam tahapan di atas, tahapan awal proses belajar dimulai dari pengalaman kongkret yang dialami seseorang. Pembelajaran dapat diawali dengan percobaan yang didemonstrasikan guru atau dengan mengamati fenomena alam. Demonstrasi ini berkaitan dengan masalah - masalah IPA yang berkaitan dengan materi. Kemudian dilanjutkan dengan tahapan observasi yaitu tahapan Pengalaman berupa percobaan secara langsung kemudian direfleksikan secara individu. Dalam proses refleksi seseorang akan berusaha untuk memehami apa yang terjadi atau dialaminya. Refleksi ini menjadi dasar konseptualisasi atau proses pemahaman prinsip-prinsip yang mendasari pengalaman yang dialami serta perkiraan kemungkinan aplikasinya dalam situasi (konteks) yang baru, atau mengaplikasikan dalam kehidupannya sebagai kegiatan pemantapan konsep yang telah dipelajari.

\section{Pembelajaran IPA SD}

Kata "IPA "merupakan singkatan kata "Ilmu Pengetahuan Alam". Katakata "Ilmu Pengetahuan Alam "merupakan terjemahan dari kata-kata Bahasa Inggris" Natural Science" secara singkat sering disebut "Science ". Natural artinya alamiah, berhubungan dengan alam atau bersangkut paut dengan alam. Science artinya ilmu pengetahuan. Jadi Ilmu Pengetahuan Alam (IPA) atau science itu secara harfiah dapat disebut sebagai ilmu tentang alam ini. Ilmu yang mempelajari peristiwa-peristiwa yang terjadi di alam. Untuk selanjutnya kita akan menggunakan kata IPA sebagai suatu istilah. (Iskandar: 2001).

Sains merupakan ilmu empirik yang membahas tentang fakta dan gejala alam maka dalam pembelajarannya harus factual, artinya tidak hanya secara verbal sebagaimana terjadi pada pembelajaran secara tradisional (Muslichah:2006).Jadi sains merupakan Ilmu Pengetahuan Alam yang mempelajari tentang alam beserta isinya baik hayati maupun non hayati .

Berdasarkan KTSP (Kurikulum Satuan Pendidikan) tujuan dari mata pembelajaran IPA adalah agar siswa memiliki kompetensi sebagai berikut :

1) Memperoleh keyakinan terhadap Tuhan Yang Maha Esa berdasarkan keberadaan, keindahan, dan keteraturan alam ciptaan NYA.

2) Mengembangkan pengetahuan dan pemahaman konsep - konsep IPA yang bermanfaat dan dapat diterapkan dalam kehidupan seharihari. 
3) Mengembangkan rasa ingin tahu, sikap positif dan kesadaran tentang adanya hubungan yang saling mempengaruhi antara IPA, lingkungan, teknologi dan masyarakat.

4) Mengembangkan keterampilan proses untuk menyelidiki alam sekitar, memecahkan masalah dan mengambil keputusan.

5) Meningkatkan kesadaran untuk berperan serta dalam memelihara, menjaga, dan melestarikan alam sekitar.

\section{Metode Penelitian}

\section{Jenis dan Rancangan Penelitian}

Penelitian ini merupakan penelitian tindakan kelas, dengan tujuan untuk mengetahui peningkatan keterampilan guru dalam pembelajaran IPA dan mengetahui peningkatan hasil belajar IPA melalui model pembelajaran experiential learningpada siswa kelas V SDN Bulukantil Surakarta tahun ajaran 2014/2015, dengan tahapan sebagai berikut :

\section{a. Perencanaan}

Perencanaan awal berupa telaah terhadap mata pelajaran Ilmu Pengetahuan Alam (IPA) di kelas V SDN Bulukantil Surakarta, kemudian menyusun RPP (Rencana Pelaksanaan Pembelajaran) dengan materi pokok organ tubuh manusia dan hewan 1) mengidentifikasi alat pernapasan pada manusia 2 ) menjelaskan fungsi alat pernapasan manusia 3) mengidentifikasi alat pencernaan makanan pada manusia. Peneliti merencanakan tindakan dalam 2 siklus.

\section{b. Pelaksanaan Tindakan}

Pelaksanaan tindakan dilakukan dengan mengimplementasikan dari perecanaan yang telah dipersiapkan yaitu pelaksaan pembelajaran dengan model experiential learningyang diuraikan dalam siklus I dan siklus II.

\section{c. Observasi}

Kegiatan observasi dilakukan secara kolaboratif dengan melibatkan guru mata pelajaran IPA dan penelitian ini juga berkolaborasi dengan kepala sekolah dan 1 (satu) orang pengamat untuk mengetahui dan mendiskripsikan keterampilan guru dalam penerapan model pembelajaranexperiential learning.

\section{d. Refleksi}

Setelah mengkaji keterampilan guru dan hasil belajar siswa, menyesuaikan dengan ketercapaian indikator kinerja, maka peneliti memperbaiki kelemahan untuk siklus berikutnya agar pelaksanaannya lebih efektif.

\section{Subyek Penelitian}

Adapun yang menjadi subyek penelitian adalah guru dan siswa kelas V SDN Bulukantil Surakarta Tahun ajaran 2014/2015 semester genap, pada matapelajaran IPA dengan Kompetensi Dasar Mendeskripsikan Organ Tubuh Manusia. Dengan jumlah 30 siswa, terdiri dari 15 siswa laki-laki dan 15 siswa perempuan.

\section{SiklusPenelitian}

\section{a. Siklus I}

1) Tahapan Perencanaan antara lain: 
- Membuat skenario pembelajaran dengan menyusun RPP.

- Membuat dan menyiapkan alat peraga dan media pembelajaran.

- Membuat lembar observasi sebagai pedoman pengamatan kegiatan.

- Menyusun alat evaluasi.

2) Tahapan Pelaksanaan tindakan antara lain:

Sebelum pembelajar an pada siklus I dilaksanakan, siswa diberi soal pre test yang hasilnya digunakan untuk menentukan skor awal kegiatan pembelajaran pada siklus I dengan materi mengidentifikasi alat pernapasan pada manusia. Langkah-langkah tindakan:

- Membentuk kelompok belajar heterogen yang terdiri dari 5 siswa.

- Merumuskan masalah yang berkaitan dengan alat pernapasan manusia.

- Siswa dalam kelompok mengungkapkan jawaban sementara dari masalah yang dirumuskan.

$\begin{array}{lr}\text { - } \text { Siswa } & \begin{array}{r}\text { mengatasi } \\ \text { permasalahan }\end{array} \\ \text { melakukan } & \text { praktek } \\ \text { langsung } & \text { (penemuan } \\ \text { sendiri) } & \\ \text { - Siswa menganalisis hasil } \\ \text { penemuan mereka. }\end{array}$

- Siswa menyajikan hasil penemuan mereka.

3) Tahapan Observasi

Kegiatan pengamatan yang dilakukan oleh peneliti sekaligus sebagai guru yang mengampu kelas tersebut, meliputi: mencatat hasil belajar siswa, memantau kegiatan kelompok siswa dan mengamati proses transfer informasi. Sedangkan kegiatan yang dilakukan oleh observer yaitu mengamati aktivitas guru dalam pembelajaran.

4) Refleksi

Menganalisis keterampilan guru dengan bantuan observer, menganalisis hasil belajar siswa dan memperbaiki kelemahan untuk siklus berikutnya

\section{b. Siklus II}

1) Perencanaan Siklus II

- Membuat skenario pembelajaran dengan menyusun RPP.

- Membuat dan menyiapkan alat peraga serta media pembelajaran.

- Membuat lembar observasi sebagai pedoman pengamatan kegiatan.

- Menyusun alat evaluasi.

2) Pelaksanaan tindakan

Langkah-langkah tindakan yang dilakukan pada pelaksanaan tindakan siklus II meliputi :

- Membentuk kelompok belajar heterogen yang terdiri dari $4-5$ siswa. 
- Merumuskan masalah yang berkaitan dengan alat pernapasan manusia.

- Siswa dalam kelompok mengungkapkan jawaban sementara dari masalah yang dirumuskan.

- Siswa mengatasi permasalahan dengan melakukan praktek langsung (penemuan sendiri)

- Siswa menganalisis hasil penemuan mereka.

- Siswa menyajikan hasil penemuan mereka.

3) Observasi

Kegiatan pengamatan yang dilakukan oleh peneliti sekaligus sebagai guru yang mengampu kelas tersebut, meliputi: Mencatat hasil belajar siswa, Memantau kegiatan kelompok siswa dan mengamati proses transfer informasi. Sedangkan kegiatan yang dilakukan oleh observer yaitu mengamati aktivitas guru dalam pembelajaran.

4) Refleksi

- Menganalisis keterampilan guru dengan bantuan observer.

- Menganalisis hasil belajar siswa.

\section{Teknik Pengambilan Data}

Dalam penelitian tindakan

kelas ini, sumber data berasal dari siswa kelas V SDN Bulukantil
Surakarta, guru kelas, dokumentasi. Jenis data yang didapatkan ada dua yaitu data kuantitatif dan data kualtatif. Data kuantitatif adalah berupa data hasil tes evaluasi siswa yang dilakukan di detiap akhir siklus. Sementara data kualitatif berupa data keterampilan guru dalam menerapkan model experiential learning.

Teknik pengumpulan data dengan cara tes dan non tes, teknik tes merupakan teknis tertulis dengan alat pengumpul data berupa soal, sedangkan teknik non tes berupa observasi dengan alat pengumpul data berupa lembar observasi.

\section{Teknik Analisis Data}

\section{a. Data Kuantitatif}

1) Data kuantitatif berupa hasil belajar kognitif, dianalisis dengan menggunakan teknik analisis deskriptif dengan menentukan mean atau rerata. Adapun penyajian data kuantitatif dipaparkan dalam bentuk presentasi dan angka. Rumus presentase tersebut adalah sebagai beriket:

(Zainal Aqib, $2010: 41$ )—

2) Nilai rata-rata didapat dengan menggunakan rumus $=\Sigma$

Dengan $\mathrm{x}=$ jumlah semua nilai siswa, $\mathrm{N}=$ jumlah siswa.

$$
\text { ( Zainal Aqib,2010:40) }
$$

Hasil perhitungan dikonsultasikan dengan kriteria ketuntasan belajar siswa yang dikelompokkan ke dalam dua kategori tuntas dan tidak tuntas, dengan 
kriteria ketuntasan $\geq 75$ dan nilai $\leq$ 75 tidak tuntas (sumber KKM Mata Pelajaran IPA di SDN Bulukantil Surakarta).

\section{b. Data kualitatif}

Data kualitatif merupaan data hasilobservasi keterampilan guru dalam menerapkan model experiential learning. Dengan kriteria keberhasilan keterampilan guru sebagai berikut:

Tabel 1. Kriteria Keberhasilan Keterampilan Guru

\begin{tabular}{|c|c|c|c|}
\hline \multicolumn{3}{|c|}{ Pencapaian } & \multirow[b]{2}{*}{$\begin{array}{c}\text { Tingkat } \\
\text { Keberhasilan } \\
\text { Pembelajaran }\end{array}$} \\
\hline $\begin{array}{c}\text { Tujuan } \\
\text { Belajar } \\
(\%)\end{array}$ & $\begin{array}{c}\text { Skor / } \\
\text { Nilai }\end{array}$ & Kategori & \\
\hline $85-100$ & 4 & $\begin{array}{l}\text { Sangat } \\
\text { Baik (SB) }\end{array}$ & Berhasil \\
\hline $65-84$ & 3 & Baik (B) & Berhasil \\
\hline $45-64$ & 2 & Cukup (C) & Tidak Berhasil \\
\hline $25-44$ & 1 & Kurang (K) & Tidak Berhasil \\
\hline $0-24$ & 0 & $\begin{array}{l}\text { angat } \\
\text { Kurang(SK) }\end{array}$ & Tidak Berhasil \\
\hline
\end{tabular}

(Aqib, $2008: 161$ )

\section{c. Indikator Keberhasilan}

Model Pembelajaran experiential learning dapat meningkatkan hasil belajar siswa dan keterampilan mengajar guru pada siswa kelas V SDN Bulukantil Surakarta, dengan kriteria sebagai berikut:

1) Keterampilan guru dalam pembelajaran IPA melalui Model Pembelajaran experiential learning meningkat dengan kriteria sekurangkurangnya baik dengan presentase minimal $65 \%$.

2) Sebesar $80 \%$ dari seluruh siswa yang diteliti di kelas V SDN Bulukantil Surakarta mengalami ketuntasan belajar dalam pembelajaran IPA khususnya dalam pencapaian kompetensi dasar mengidentifikasi fungsi organ tubuh manusia dan hewan.

\section{Hasil Penelitian dan Pembahasan}

\section{Data Hasil Belajar Siswa}

Berdasarkan hasil penelitian pada pembelajaran IPA dengan menggunakanModel Pembelajaran experiential learning pada siswa kelas V SDN Bulukantil Surakarta diperoleh data peningkatan hasil belajar siswa dari siklus I ke siklus II. Secara lebih jelas dapat dilihat pada tabel 2 di bawah ini:

Tabel 2. Peningkatan Hasil Belajar Siswa

\begin{tabular}{clccc}
\hline No & Hasil Belajar & Data Awal & Siklus I & Siklus II \\
\hline 1 & Nilai tertinggi & 70 & 90 & 90 \\
\hline 2 & Nilai terendah & 30 & 40 & 65 \\
\hline 3 & Rata-rata & 50,72 & 61,07 & 75,09 \\
\hline 4 & Tuntas belajar & $42,8 \%$ & $60,7 \%$ & $85 \%$ \\
\hline 5 & Tidak tuntas belajar & $57,2 \%$ & $39,3 \%$ & $15 \%$ \\
\hline
\end{tabular}

Berdasarkan tabel di atas dapat di sajikan dalam diagram batang di bawah ini : 


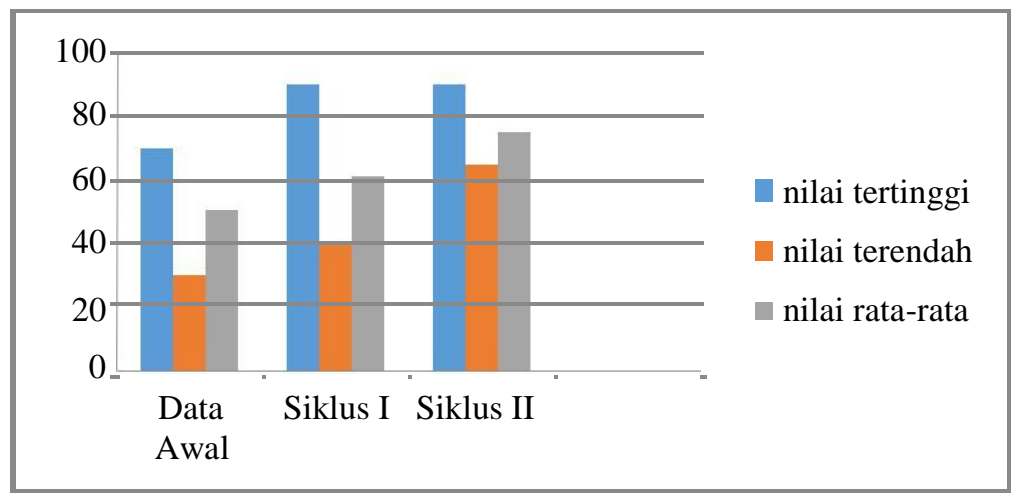

Diagram 1. Diagram hasil belajar siswa Siklus I

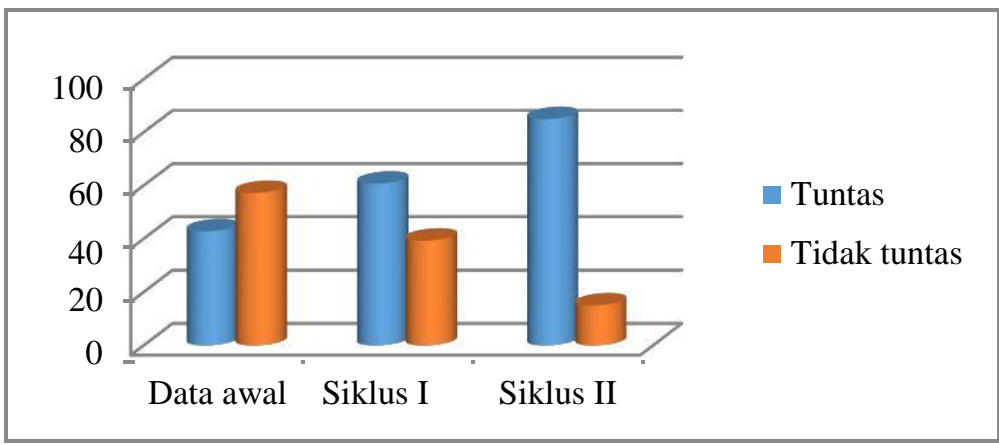

Diagram 2. Diagram Peningkatan Ketuntasan Belajar Siswa

Berdasarkan hasil penelitian tersebut bahwa terdapat peningkatan hasil belajar IPA menggunakan Model Pembelajaran experiential learning dari siklus I ke siklus II. Hasil belajar siklus 1 nilai rata-ratanya adalah 61,07 dengan ketuntasan beljajar klasikal $60,7 \%$. Untuk siklus II nilai rataratanya adalah 75,09 dengan ketuntasan belajar klasikal $85 \%$,

Menurut data di atas terdapat kenaikan hasil belajar serta kenaikan ketuntasan belajar klasikal dari siklus ke siklus dari $60,7 \%$ menjadi $85 \%$, terjadi peningkatan ketuntasan belajar sebesar 24,3 \%. Hal tersebut dikarenakan dalam tahapan pembelajaran guru melakukan kegiatan perbaikan secara terencana dan sistematis.
Nilai ketuntasan merupakan suatu nilai yang menggambarkan proporsi dan kualifikasi penguasaan peserta didik terhadap kompetensi pembelajaran. Untuk mengunakan batas minimal nilai ketuntasan siswa dapat menggunakan pedoman yang sudah ada disekolah.

Salah satu yang dapat berpengaruh terhadap ketuntasan nilai dalam pembelajaran adalah dengan menggunakan Model Pembelajaran experiential learningyaitu siswa diberikan penggambaran realitas secara langsung sebagai pengalaman yang ditemui pertama kalinya, dimana hal ini masih sangat nyata (kongkret). Dalam ini tahap pembelajaran di lakukan dengan cara memegang, merasakan atau mencium secara langsung yang berhubungan dengan materi pelajaran. Misalnya pada Kompetensi Dasar (KD) menjelaskan pernafasan pada manusia. 
Siswa secara langsung praktik uji pernafasan (membuat model paruparu, pembuktian sisa hasil pernafasan, dan pembuktian ganguan pernafasan).

Menurut Edgar Dale dalam (Hamid Muhammad, 2005: 4) mengemukakan pengalaman belajar yang disebut dengan kerucut pengalaman belajar. Disebut sebagai kerucut karena terbentuk dari sebuah segitiga yang bagian dasarnya lebih luas daripada ujungnya. Berikut ini disajikan dalam kerucut pengalaman belajar:

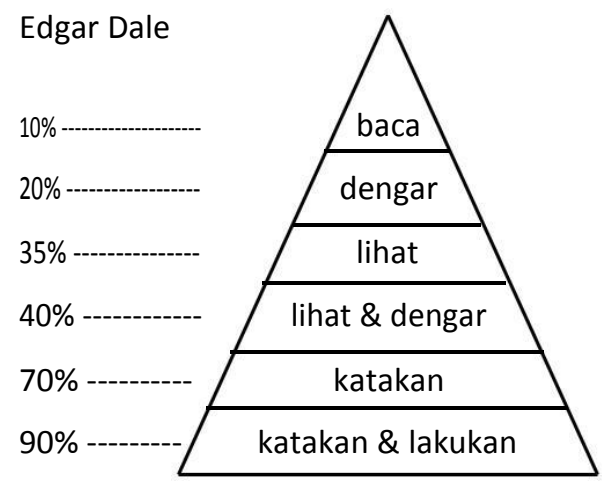

Gambar 1. Kerucut Pengalaman Edgar Dale 1969
Sesuai dengan pendapat dari Edgar Dale bahwa sumber belajar itu adalah pengalaman.Maksud dari penjelasan diatas bahwa pengalaman belajar yang diperoleh siswa dapat melalui proses perbuatan atau mengalami sendiri apa yang dipelajari, proses mengamati, dan mendengarkan melalui media tertentu. Semakin konkret siswa mempelajari bahan pengajaran, maka semakin banyaklah pengalaman yang diperolehnya.

\section{Hasil Observasi Keterampilan Guru.}

Hasil observasi ketrampilan guru pada pembelajaran IPA menggunakan Model Pembelajaran experiential learningdari siklus I ke siklus II mengalami peningkatan. Secara lebih jelas dapat dilihat pada tabel 3 di bawah.

Tabel 3. Peningkatan Keterampilan Guru pada Siklus I dan II

\begin{tabular}{clcc}
\hline No & \multicolumn{1}{c}{ Indikator } & $\begin{array}{c}\text { Perolehan skor } \\
\text { siklus I }\end{array}$ & $\begin{array}{c}\text { Perolehan } \\
\text { skor siklus II }\end{array}$ \\
\hline 1 & Guru mempersiapkan pembelajaran & 4 & 4 \\
\hline 2 & $\begin{array}{l}\text { Guru menggunakan model experiential } \\
\text { learning }\end{array}$ & 3 & 4 \\
\hline 3 & $\begin{array}{l}\text { Guru mengajuksan pertanyaan berkaitan } \\
\text { dengan materi }\end{array}$ & 3 & 4 \\
\hline 4 & Guru menjelaskan materi pelajaran & 3 & 4 \\
\hline 5 & $\begin{array}{l}\text { Mengelola ruang, waktu dan fasilitas } \\
\text { belajar }\end{array}$ & 3 & 4 \\
\hline 6 & $\begin{array}{l}\text { Guru mengajukan pertanyaan berkaitan } \\
\text { dengan materi }\end{array}$ & 3 & 3 \\
\hline 7 & Guru membimbing diskusi kelompok & 3 & \\
\hline
\end{tabular}




\begin{tabular}{llcc}
\hline No & Indikator & $\begin{array}{c}\text { Perolehan skor } \\
\text { siklus I }\end{array}$ & $\begin{array}{c}\text { Perolehan } \\
\text { skor siklus II }\end{array}$ \\
\hline 8 & $\begin{array}{l}\text { Guru membimbing kelompok kecil atau } \\
\text { perorangan }\end{array}$ & 3 & 3 \\
\hline 9 & Guru menutup pelajaran & 3 & 3 \\
\hline Jumlah skor rata-rata & 3,11 & 3,5 \\
\hline Presentase & $77,7 \%$ & $88,8 \%$ \\
\hline Kategori & Baik & Sangat Baik \\
\hline
\end{tabular}

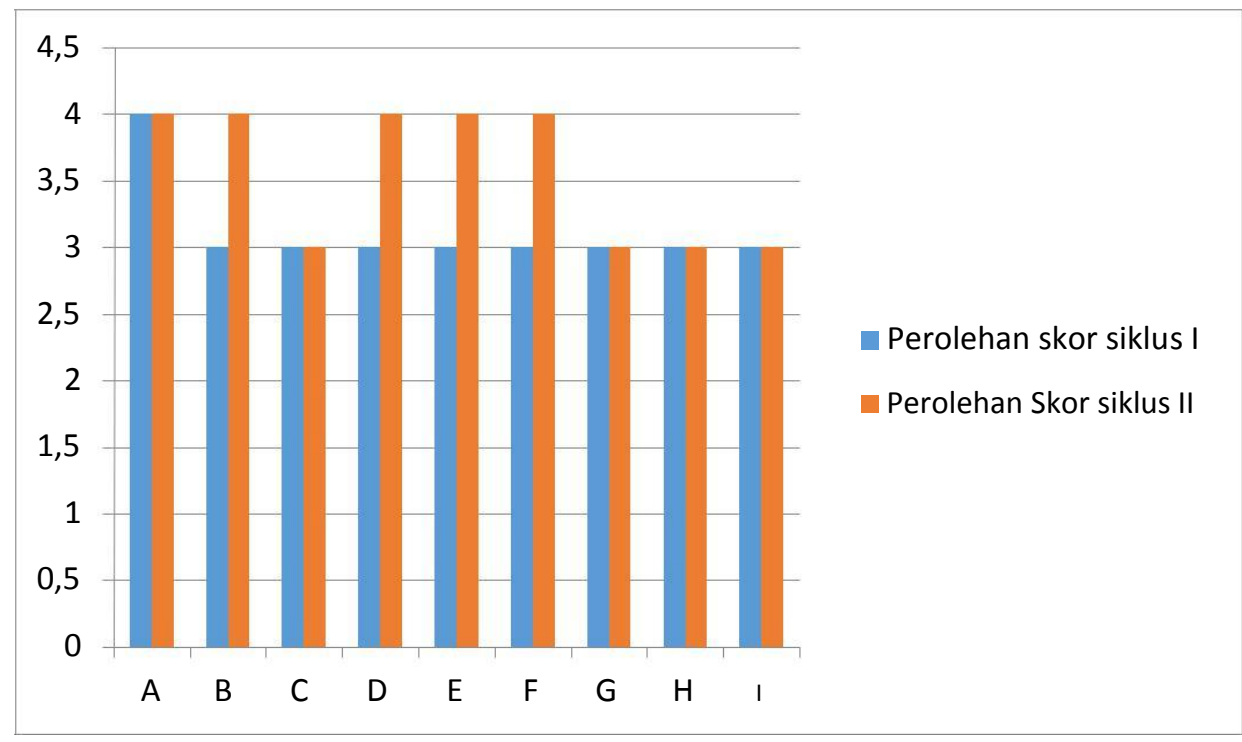

Diagram 3. Diagram peningkatan Keterampilan Guru dari Siklus I ke Siklus II

Hasil observasi keterampilan guru tersebut sebagai penilaian indikator keberhasilan penelitian melalui Model Pembelajaran experiential learning untuk meningkatkan kualitas pembelajaran IPA di kelas V SDN Bulukantil Surakarta, kerampilan guru yang diamati pada penelitian ini mengacu kepada delapan keterampilan guru. Secara rinci tiap indikator disajikan sebagai berikut.

\section{a. Guru mempersiapkan pembelajaran}

Berdasarkantabeldan diagram ketrampilan guru dari siklus I mendapat skor 4 disiklus II mendapat skor 4 dengan kategori sangat baik. Hal itu terbukti dari empat deskriptor yang muncul yaitu sebelum pembelajaran dimulai guru sudah menyiapkan semua yang diperlukan dalam pembelajaran seperti materi dan media. Guru menyiapkan kesiapan belajar siswa untuk memulai pembelajaran dengan mengkondisikan siswa ditempat duduknya masingmasing kemudian mengecek kehadiran siswa. Keterampilan guru yang tampak dalam mempersiapkan pembelajaran sesuai dengan pendapat Mulyasa yang mengemukakan bahwa membuka 
pelajaran bertujuan untuk menciptakan kesiapan mental dan menarik perhatian peserta didik secara optimal agar terpusat sepenuhnya untuk belajar (Mulyasa, 2009:181).

\section{b. Guru menggunakan model experiential learning}

Berdasarkan tabel

keterampilan guru dari siklus I mendapatkan skor3, selanjutnya pada siklus II mengalami peningkatan dalam proses pembelajaran yaitu mendapat skor 4 dengan kategori sangat baik. Hal itu terbukti dari keempat deskritor yang nampak dalam kegiatan pembelajatran guru sudah menjelaskan tahapan-tahapan tau langkah-langkah dalam menggunakan model experiential learningyaitu tahapan pengalaman nyata, tahapan Observasi refleksi, tahapan konseptualisasi, tahapan implementasi.

\section{c. Guru mengajukan pertanyaan}

Indikator ini terdapat beberapa deskriptor penjabaran yakni, guru memberikan pertanyaan dengan kalimat yang jelas dan mudah di mengerti, guru juga memberikan waktu untuk berpikir, merespon dengan ramah atas jawaban dari siswa, serta guru memberikan umpan balik dengan mengajukan pertanyaan yang menarik.

Dalam pembelajaran IPA pada siklus I skor 3 guru telah memberikan pertanyaan dengan kalimat yang jelas dan mudah di mengerti, guru juga merespon siswa dengan ramah atas jawaban siswa, serta guru memberikan umpan balik dengan mengajukan pertanyaan yang menarik. Pada siklus II juga mengalami peningkatan dengan mendapat skor 3 dengan kategori baik. Hal ini sesuai dengan pendapat menurut Usman (2009:74) bertanya harus dengan pertanyaan yang tersusun dengan baik dan teknik pelontaran yang tepat.

\section{d. Guru menjelaskan materi pembelajaran}

Berdasarkan tabel keterampilan

guru, pada siklus I mendapatkan skor 3, sedangkan pada siklus II mendapat skor 4. Hal itu terbukti dari empat deskriptor yang nampak yaitu guru melibatkan siswa untuk mengemukakan pendapat dan berusaha meluruskan pendapat siswa yang kurang tepat, guru memberikan contoh-contoh yang lebih kompleks mengenai materi yang sedang diajarkan. Serta guru membimbing siswa memahami konsep materi yang sedang dipelajari. Hal ini sesuai dengan pendapat Usman (2009:88) yang menyatakan bahwa penyampaian materi tidaklah dilakukan sembarangan, melainkan harus memperhatikan prinsipprinsip keterampilan menjelaskan diantaranya seperti kejelasan, penggunaan contoh dan ilustrasi,pemberian tekanan dan balikan.

\section{e. Mengelola ruang, waktu dan fasilitas belajar}

Berdasarkan tabel keterampilan guru, pada siklus I mendapatkan skor 3, sedangkan pada siklus II keterampilan guru dalam menjelaskan materi 
pembelajaran mengalami peningkatan dengan mendapat skor 4 dengan kategori sangat baik. Hal ini terbukti dari empat descriptor yang nampak yaitu guru dalam menyiapkan kondisi belajar yang optimal, memberikan petunjuk dengan jelas, ketepatan dalam menggunakan alokasi waktu dan menegur siswa yang berperilaku menyimpang pada saat pembelajaran berlangsung. Hal ini sesuai dengan pendapat Usman (2009:97) yang menyatakan bahwa Pengelolaan kelas merupakan keterampilan guru untuk menciptakan dan memelihara kondisi belajar yang optimal dan mengembalikannya bila terjadi gangguan.

\section{f. Guru membimbing diskusi kelompok}

Berdasarkan tabel

keterampilan guru, dari siklusI mendapatkan skor 3, sedangkan pada siklus II keterampilan guru dalam diskusi kelompokmengalami peningkatan dengan mendapat skor 4. Hal iti terbukti dari empat descriptor yang nampak yaitu guru dapat memusatkan perhatian siswa dengan menggunakan sumber belajar langsung dari lingkungan,meningkatkan partisipasi siswa, serta mencegah dominasi siswa dalam berdiskusi kelompok. Hal ini sesuai dengan pendapat Usman (2009:94) tentang diskusi kelompok adalah proses teratur yang melibatkan sekelompok orang dalam interaksi tatapmuka dengan berbagai pengalaman dan informasi untuk memecahkan suatu permasalahan.

\section{g. Guru membimbing kelompok kecil atau perorangan}

Berdasarkan tabel keterampilan guru, dari siklusI mendapatkan skor 3, sedangkan pada siklus II keterampilan guru dalam diskusi kelompokmengalami peningkatan dengan mendapat skor 3 dengan kategori sangat baik dan pada Siklus III juga mendapatkan skor3. Hal iti terbukti dari empat descriptor yang nampak yaitu guru memberikan rasa aman dan menyenangkan sehingga siswa berani maju untuk mempresentasikan hasil diskusinya, guru juga melakukan pendekatan secara pribadi pada siswa dengan bersikap sebagai sahabat, serta guru juga membantu siswa dalam memahami materi yang belum dimengerti. Hal ini sesuai dengan pendapat Usman (2009:102) bahwa membimbing kelompok kecil atau perorangan tidak berarti guru hanya menghadapi satu kelompok atau seorang siswa saja. Namun guru memberikan bimbingan khusus yang lebih individual untuk membantu siswa dalam belajar.

\section{h. Guru memberikan penguatan}

Berdasarkan tabel keterampilan guru, pada siklusI dan II mendapatkan skor 3, dengan kategori baik. Hal itu terbukti dari empat descriptor yang nampak yaitu guru memberikan penguatan secara verbal dan non verbal serta memberikan penguatan sesegera mungkin setelah siswa melaksanakan tugas dengan baik. Hal ini sesuai dengan 
pendapat Usman (2009:80) penguatan adalah segala bentuk respon yang bersifat verbal maupun non verbal yang bertujuan untuk memberikan informasi atau umpan balik atas tingkah laku siswa.

\section{i. Guru menutup pelajaran}

Berdasarkan tabel

keterampilan guru, dari siklusI dan II mendapatkan skor 3 dengan kategori baik. Hal itu terbukti dari empat descriptor yang nampak yaitu guru sudah melakukan refleksi dengan bertanya kepada siswa "bagaimana perasaan kalian dengan pembelajaran yang telah kita laksanakan tadi? Apakah masih ada hal-hal yang belum kalian pahami?. Setelah menyimpulkan dan memberikan refleksi guru memberikan soal evaluasi untuk dikerjakan secara individu, dalam mengakhiri pembelajaran guru mengucapkan salam. Sesuai dengan pendapat Mulyasa (2009:185) bahwa dalam kegiatan penutup guru berupaya mengetahui pembentukan kompetensi dan pencapaian tujuan pembelajaran serta pemahaman peserta didik mengenai materi yang dipahami.

Berdasarkan hasil observasi ketrampilan guru diatas, maka dalam kegiatan pembelajaran guru tidak hanya sebagai transformator tetapi mampu sebagai fasilitator, motivator dan evaluator. Hal tersebut menghadapkan siswa pada pengalaman kongkrit sehingga siswa dapat mengembangkan ketrampilan berpikir kritis, termotivasi untuk terlibat langsung. Dengan demikian pembelajaran yang dikehendaki pada kurikulum KTSP IPA menekankan keterlibatan siswa secara aktif dapat terlaksana dengan baik.

\section{E. Simpulan dan Saran}

Berdasarkan hasil penelitian tentang penerapan model pembelajaran experiential learning dalam pernbelajaran IPA pada siswa kelas V SDN Bulukantil Surakarta, maka dapat disimpulkan: (1) Terjdi peningkatan hasil belajar siswa yang ditandai dengan tercapainya ketuntasan belajar klasikal dalam pembelajaran IPA khususnya dalam pencapaian kompetensi dasar mengidentifikasi fungsi organ tubuh manusia yaitu dari siklus I $60.7 \%$ menjadi $85 \%$ pada siklus II, naik sebesar $24,3 \%$.

(2) Terjadi peningkatan keterampilan guru dalam tiap-tiap siklusnya. Guru terampil rnengelola proses belajar mengajar IPA dengan menerapkan model pembelajaran experiential learningyang ditandai dengan hasil ratarata guru memenuhi kriteria baik yaitu Pada siklus I rata-rata keterampilan guru yang diperoleh 3,11 dengan persentase $77.7 \%$ (baik), siklus II meningkat lebih baik lagi menjadi 3,5 dengan persentase $88.8 \%$ (sangat baik).

Berdasarkan Kesimpulan penelitian saran-saran yang disampaikan adalah (1)Penguasaan model pembelajaran yang inovatif memungkinkan berkembangnya potensi siswa, guru harus mampu memberi motivator sekaligus menjadi fasilitator bagi siswanya. Hal ini akan merangsang 
diri siswa sehingga akan mempercepat pemahaman dalam belajar. (2) Suatu keberhasilan dalam bentukan prestasi belajar tidak bergantung pada orang lain tetapi lebih banyak ditentukan oleh diri sendiri. Untuk itu siswa harus terlibat secara penuh baik secara fisik maupun mental dalam proses belajar mengajar, hal ini akan mempermudah tercapainya tujuan belajar. (3) Dalam upaya mengembangkan pembelajaran yang efektif dan efisien. model pembelajaran experiential learning perlu diterapkan terutama dalam pembelajaran IPA.

\section{Daftar Pustaka}

Arikunto, Suharsimi. 2002. Prosedur Penelitian Suatu Pendekatan Praktek. Jakarta: PT. Rineka Cipta.

Aqib, Zaenal. 2010.Karya Tulis lmiah. Bandung: Yrama Widya.

Dwicahyono, Aris. 2014.

Pengembangan Perangkat

Pembelajaran.

Yogyakarta: Gava Media.

Hua, Miftahul.2014. Model Model Pengajaran dan Pembelajaran. Yogyakarta : Pustaka Pelajar.

Majid, A dan Rochman, C. 2014. Pendekatan Ilmiah dalam Implementasi Kurikulum 2013. Bandung : Rosdakarya.
Muhammad, Hamid. 2005.Ilmu Pengetahuan Alam. Bandung : FMIPA UPI.

Mulyasa. 2009. Menjadi Guru Profesional Menciptakan Pembelajaran Kreatif dan Menyenangkan. Bandung: Rosdakarya.

Mulich, Masnur. 2009. Melaksanakan Penelitian Tindakan Kelas itu Mudah. Jakarta : PT Bumi Aksara.

Sanjaya, Wina. 2011. Strategi Pembelajaran Berorientasi Standar Pendidikan. Jakarta : Kencana Prenada Media.

Slameto. 2010. Belajar dan Faktorfaktor yang mempengaruhi. Jakarta : Rineka Cipta.

Sugyono. 2010. Metode Penelitian Pendidikan. Bandung : Alfabet.

Sarini, M.Iskandar. 2001. Pendidikam Ilmu Pengetahuan Alam. Bandung : CV Maulana. 
